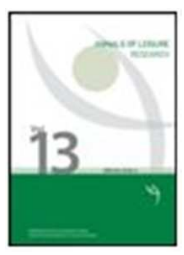

Nature Sports, Health and Ageing: the Value of Euphoria

\begin{tabular}{|r|l|}
\hline Journal: & Annals of Leisure Research \\
\hline Manuscript ID & Draft \\
\hline Manuscript Type: & Special Issue Article \\
\hline Keywords: & adventure, tourism, ageing, psychology, health, economics \\
\hline & \\
\hline
\end{tabular}

SCHOLARONE $^{\text {IM }}$

Manuscripts 


\title{
Nature Sports, Health and Ageing: the Value of Euphoria.
}

\begin{abstract}
I analyse ageing trajectories in adventurous outdoor nature sports. This includes snow, water and air sports, involving boards, paddles, sails and wings. Skill and risk levels are intermediate. Training and experience are required, and safety precautions are routine, but the risk of death is low. Capability, and challenges faced, decrease at older ages, and chronic pain levels increase; but attention and appreciation of natural surroundings increase, and enjoyment and opportunities for euphoria persist. Euphoria temporarily overrides chronic pain and stress. In wealthy urbanised nations, nature sports can make major contributions to the physical, mental and social health of older individuals, and this contributes to national economies by reducing the very large costs of aged care for those in declining health. Therefore, health policies should encourage lifelong nature sports for all.
\end{abstract}

\section{Keywords}

adventure, education, recreation, tourism, ageing, health, psychology, economics

\section{Introduction}

Social attitudes to adventurous outdoor nature sports, in wealthy urbanised nations, are divided and paradoxical. For schoolchildren, and juveniles engaged in antisocial behaviours, these activities are considered beneficial, character building, and therapeutic. Adults who engage in formal competitive outdoor sports are also widely applauded. Adults who engage in non-competitive adventurous outdoor nature sports, however, are often criticised.

I argue here that participation in adventurous outdoor nature sports is at least as beneficial for adults as it is for children. These activities require high skill, extensive experience, and careful planning and safety precautions. Participants become physically, mentally and socially healthy and resilient, lead productive working lives, and contribute to their communities. These benefits extend to older individuals whose capabilities have decreased, but who can nonetheless continue to gain the same benefits, with adjustment of expectations. I argue that the key benefit of adventurous outdoor nature sports, not provided either by nonadventurous exercise or nature exposure, is that it can create euphoria, which can temporarily override chronic pain and psychological stress associated with other aspects of ageing.

In wealthy urbanised nations, average lifespan has increased substantially, but for many individuals the final years or decades are lived in poor health, and the costs of aged care and health care now represent a very substantial drain on national economies. I argue that by keeping older people healthy and happy, adventurous outdoor nature sports thus make large contributions to national economies, exceeding even their economic contributions through direct expenditure on equipment, travel and services. 


\section{Theoretical Context}

\section{Social perceptions of participants in adventurous outdoor nature sports}

Outdoor education, outdoor recreation, park visitation, nature tourism, ecotourism, adventure tourism, adventure recreation, adventure sports, extreme sports: each has slightly different connotations, but they all overlap. The choice of words depends on each author's background, the publication outlet, and the intended audience. Those same factors influence what previous literature any author is aware of, what professional experience they may have, and how they perceive the participants in any of these outdoor activities. In particular, these differences between authors, academic disciplines, and terminology adopted, influence how they think different individuals are motivated to take part in adventure activities, and whether they see those individuals as socially responsible or socially irresponsible.

Outdoor education, for example, has a very long practical history of school sports and camps, and adventure playgrounds and programs. All of these approaches are seen both by teachers and parents as being good for the participants, ie the school children. They are seen as building self esteem and self reliance, physical and mental capability, and teamwork skills (Bowen, Neill, \& Crisp, 2016; Berman \& Davis-Berman, 2013; Epstein, 2004; Ewert \& Yoshino, 2011; Hattie et al., 1997; Pryor, Carpenter, \& Townsend, 2012; Russell, 2003; Sandseter \& Kennair, 2011; Scrutton \& Beames, 2015; Sibthorp \& Arthur-Banning, 2004; Sibthorp et al., 2008). Similarly, remedial outdoor programs, for subadult individuals seen as socially delinquent, are treated as a positive influence (Gass, Gillis, \& Russell, 2012).

At the other end of the scale, however, many psychologists have written about adult adventure recreation and extreme sports as indicative of personality disorders. Why? Some of the terms used, such as sensation seeking personalities, are largely innocuous. Others, such as death wish, narcissism and regression (Elmes \& Barry, 1999), or egotism and recrimination, are less favourable (Puchan, 2004). The actual activities, and the psychological experiences of the individuals taking part, are quite similar to those used for outdoor education, but the ways in which they are perceived and written about are very different.

In addition, both public and academic attitudes to adventure athletes depend on circumstances. Competitors in many Olympic and other international sports, for example, are praised, adored, and lionised, even though they face major risks, and many are injured severely and repeatedly during training and competition. Ski jumping and bobsled racing provide examples. The same applies for many highly physical competitive team sports, and for the various forms of organised competitive pugilism and other martial arts. Individuals who measure their skills against the outdoors, in contrast, are admired by some, but criticised by many others.

Attitudes and public perceptions can change, and I suggest that this is indeed happening at the moment, in regard to public perceptions of outdoor adventure. I suggest that there are three main reasons for this. The first reason is that participants have changed how they present themselves. Public perceptions of surfers and snowboarders, for example, have shifted over the past three to five decades, from social misfits to paid professional athletes. The second reason is that large and profitable industries have arisen to provide outdoor adventure opportunities, and these industries market their sponsored athletes and participants as people to be emulated. The commercial outdoor tourism industry has gradually taken over from individual outdoor recreation, to the point where it is now a trillion-dollar global sector, 
1

2

3

4

5

6

7

prepared to play a powerful role in major political controversies. This transition, from private nature and adventure recreation, to commercial nature and adventure sports and tourism, has been studied extensively elsewhere (Buckley et al., 2015) and is not my focus here. adventure sports and activities, relates to mental health. Research in mental health, and its relations with physical and social health and quality of life, has recently begun to credit outdoor activities, including associated emotional components, for their contributions to human health and well-being. This applies particularly for office-bound urban individuals in the more wealthy and urbanised nations. This is my focus here: the importance of adventurous nature sports as outdoor therapies for mental health, and the economic value of the mental health outcomes achieved.

\section{Motivations and experiences in adventure activities and nature sports}

Many different motivations have been proposed and demonstrated for people to take part in adventurous outdoor nature sports: either individually; as members of recreational associations; or as clients of adventure tour operators. These motivations fall into two broad categories: external motivations associated with peer esteem and social capital, and internal motivations associated with self esteem and emotional reward (Buckley, 2012; Pomfret \& Bramwell, 2014; Immonen et al., 2017; Holm et al., 2017; Melo \& Gomes, 2017; Portugal et al., 2017). Skill and risk are important components of this mix, but by no means essential or even dominant.

Participant perceptions and emotions have now been analysed for a number of high-skill, high-risk adventure activities (Arijs et al., 2017; Azim, 2014; Baretta, Greco, \& Steca, 2017; Brannigan \& McDougall, 1983; Brymer, 2010; Brymer \& Oades, 2009; Brymer \& Mackenzie, 2017; Brymer \& Schweitzer, 2013a,b, 2017a,b; Buckley, 2012, 2015b, 2016a,b; Holm et al., 2017; Holmborn, Brymer, \& Schweitzer, 2017; Immonen et al., 2017; Monasterio et al., 2016; Niedermeier et al., 2017; Portugal et al., 2017; Seifert et al., 2017; Willig, 2008). Overcoming fear is an important component (Buckley, 2016a; Miesel \& Potgieter, 2003), but risk is generally seen as something to be minimised and managed, not as a motivation in itself. Parallel research in natural and other settings has also examined phenomena such as self-perceived near-death experiences (Thonnard et al., 2013; Moore \& Greyson, 2017); the functions of consciousness (Earl, 2014); and the individual perception of slowed time when at high risk of immediate death (Arstila, 2012; Buckley, 2014; Stetson, Fiesta \& Eagleman, 2007; Wittman, 2011).

The phenomenological concept of ineffability, experiences that are indescribable, has been examined extensively in the context of extreme sports (Brymer \& Oades, 2009; Brymer \& Mackenzie, 2017; Brymer \& Schweitzer, 2017a,b; Holmbom et al., 2017). Buckley (2012) argued that at least some apparently ineffable adventure experiences could indeed be described, using the concept of rush, as a combination of thrill and flow. As an alternative to ineffability, emotions that are undescribable, Woodman et al. (2010) argued that individuals who take part in adventure activities suffer differentially from alexithymia, difficulty in describing one's emotions. Authors such as Hickman et al. (2016, 2017), Holmbom et al. (2017), and Wheaton (2017), however, report interviews with expert adventure practitioners who do indeed describe their emotions, albeit not in the terminology adopted in psychological research. 
148

149

150

151

152

153

154

155

156

157

158

159

160

161

162

163

164

165

166

167

168

169

170

171

172

173

174

175

176

177

178

179

180

181

182

183

184

185

186

187

188

189

190

191

192

193

194

195

196

197

\section{Effects of ageing on adventure participation and experiences}

Ageing affects many human characteristics relevant to adventure activities, and it may also affect individuals' abilities to recall those activities. For most people, memory declines with age, though some individuals, known as superagers, maintain the recall abilities of those 2030 years younger (Sun et al., 2016). Cognitive abilities generally do not decline with age for those still in the workforce (Brough et al., 2011). They do, however, decline at later ages.

Laslett (1991) proposed four ageing stages in the human lifecycle: child, adult, third age, and fourth age. The third age is the age of bucket lists: individuals who have retired from fulltime work, and have the means, time, and capabilities to pursue leisure goals. The fourth age begins when capabilities decrease so far that goals are no longer reachable, and individuals become "dependent and decrepit" (Laslett, 1991). This distinction led to the concept of "successful ageing" (Boyes, 2013), where individuals retain sufficient physical and psychological resilience to prolong their "third age" as far as possible.

Extensive recent research has shown that continuing physical exercise is good for human health even at advanced ages (DiPietro et al., 2017). Physical fitness also helps to maintain brain function in older individuals, as measured by gray matter volume (Erickson, Leckie, \& Weinstein, 2014). Older people take fewer risks (Boyes, 2013) and this is associated with neuroanatomical changes (Grubb et al., 2016). Steptoe, Deaton \& Stone (2014) found that subjective self-assessed wellbeing, for individuals in wealthy Anglophone nations, is lowest at age 50, but highest at age 70 . Their study did not survey respondents aged above 75 . Individuals at age 70 reported more pain, but less worry or stress. Orth, Maes \& Schmitt (2015) found that self-esteem is highest at age 60, and begins to decline at greater ages. This applies irrespective of demographic factors. Wooden and $\mathrm{Li}$ (2016) reported that life satisfaction in Australia remains approximately constant from age 25-65, but then falls abruptly.

There seem to be rather few recent qualitative studies that focus specifically on individual adventure athletes' perceptions of ageing. There are interview-based studies of: $7 \mathrm{New}$ Zealand hikers and bikers aged 63-80 (Boyes, 2013); 8 Scottish rock-climbers and 7 seakayakers aged 65+ (Hickman et al., 2016); 10 climbers aged 65-75 (Hickman et al., 2017); and 11 British surfers aged 45-70 (Wheaton, 2017). Buckley (2017) argued that individual participants in adventurous outdoor nature sports go through a "leisure lifepsychle" reflecting the psychological trajectory of ageing.

[author] (in rev) argued that ageing adventure athletes pass through two major thresholds in self-esteem. The first occurs when individuals realise that younger friends and colleagues, previously less skilled than themselves, are now more skilled. That is, they themselves are no longer leaders. The second occurs when individuals realise that they are no longer even a neutral independent addition to a group; they have become a burden, someone whom the younger members respect for past achievements, but not current capabilities. [author] (in rev) argues that ageing adventure athletes must adjust their aspirations, and reassess they achievements, in order to avoid loss of self esteem. 
1

2

3

4

5

6

7

8

\section{Nature, human health, \& outdoor therapies}

Nature contributes to human health at many scales, from planetary-scale ecosystem processes to individual people. Here I consider only the latter, the health gains achieved by individuals who spend time in natural surroundings. These gains derive from both physical and psychological components. Exercise has demonstrated therapeutic benefits for at least 26 different physical and psychological conditions (Pedersen and Saltin, 2015). This applies even for "weekend warrior" exercise patterns (O'Donovan et al., 2017). Exercise can prevent depression (Harvey et al., 2017) and improve cognition (Gomez-Pinilla \& Hillman, 2013). In experiments with mice, Sah et al. (2017), and Vivar \& van Praag (2017) found that the act of running itself causes detectable physical changes in the brain.

Young et al. (2017) identified a cascade effect, whereby exercise improves social and psychological as well as physical health. Lee, Brellenthin, et al. (2017) showed that runners live 3 years longer, on average, than non-runners. Very detailed modelling by Lee, Adam, et al. (2017) showed that current low levels of exercise amongst children in the USA will cost the US economy \$2.8 trillion (measured as net present value) over the course of their lifetimes. Exercise outdoors yields greater improvement than exercise indoors (Coon et al., 2011; Frühauf et al., 2016; Niedermeier et al., 2017; Pasanen, Tyrväinen, \& Korpela, 2014). Adventurous activities in nature and natural settings yield a range of health benefits (Mantler \& Logan, 2015; Luttenberger et al., 2015; Hendriks et al., 2016; Seymour, 2016; Biedenweg, Scott, \& Scott, 2017; Niedermeier, Hartl, \& Kopp, 2017; Oh et al. 2017).

These links have been proposed as the basis for outdoor nature, eco and adventure therapies (Buckley \& Brough, 2017a; Buckley, Brough \& Westaway, 2018; Clough et al., 2016; Frumkin et al., 2017). A range of research is still required to bring this to fruition. For example, the effects of these interventions differ both between individuals (Blaschke et al., 2017; Wang et al., 2017) and between environments (Immonen et al., 2017; Triguero-Mas et al., 2017; Wyles et al., 2017). Because of the high social and economic costs of poor mental health (Zeisel et al., 2016; Lee et al., 2017), the contribution of adventurous outdoor nature sports to mental health can create economic value for parks and other places particularly suitable for such activities (Buckley \& Brough, 2017; Smith, Roux \& Hayes, 2017). Such economic valuations are increasingly important in land allocation and policy (Rabarison et al., 2015; Jepson, et al., 2017).

A number of recent reviews (Buckley \& Brough, 2017a; Frumkin et al., 2017; Seymour, 2016) have assembled evidence from a very wide range of clinical, experimental, and correlational studies showing that nature exposure yields health benefits. These benefits accrue across: a wide range of exposure types and intensities; a wide range of physical, mental and social health parameters; and a wide range of human cultures, ages, socioeconomic statuses, and prior mental health conditions. Most of these studies have measured only a limited set of parameters, and considered only brief low-intensity exposures. With few exceptions (Niedermeier et al., 2017a,b), the effects of lifetime involvement in adventurous outdoor nature sports have received little attention in the healthcare literature.

These reviews conclude that at population scale, poor mental health imposes a range of social and economic costs on the economies of developed nations, in aggregate equivalent to around $10 \%$ of their GDP (Buckley \& Brough, 2017a,b). They also conclude that these costs can be alleviated through increased exposure to nature. Critical information to calculate the exact financial value is currently lacking (Buckley \& Brough, 2017a), though relevant research is 
248

under way. Estimates currently available indicate a greater value for nature through its contributions to human mental health, than that achieved through expenditure on tourism.

To convert this value into realisable economic gains will require the routine incorporation of outdoor nature, eco and adventure therapies into clinical and public healthcare systems (Buckley \& Brough, 2017b; Buckley, Brough \& Westaway, in rev.; Buckley, Westaway \& Brough, 2016; Clough et al., 2016). As for any other type of therapy, one of the steps needed to achieve this is to create menus of certified, insured, and prescribable outdoor therapies, customised to patient characteristics and mental health conditions. This needs an extensive program of research that considers and tests a wide range of outdoor activities for different circumstances and patient groups (Frumkin et al., 2017). These activities will need to include adventure and nature sports, as well as passive nature contemplation.

To design and establish such a program, we can first draw on existing research literature in outdoor education, recreation, tourism and leisure studies. Whilst little of that research set out to design or test therapeutic healthcare, it does considers much more intense experiences than the nature-health literature, and much longer timespans, often extended over entire lifetimes. What can we extract or deduce, in relation to the mental health of participants, from the literature on outdoor nature and adventure sports, education, recreation and tourism? Can we partition the results by age, cultural background, personality, or socioeconomic status; or by the type, intensity, risk, emotional components, frequency, duration, and setting of the activities? Here, as outlined above, I focus on the effect of ageing.

\section{Methods}

\section{Intermediate Skill \& Risk Levels}

Here I present an autoethnographic analysis of ageing trajectories in a set of adventurous nature sports, carried out at intermediate skill and risk levels (Table 1). Few of these, except for aerobatic hanggliding four decades ago, are extreme in the sense that miscalculation means death (Brymer, 2013; Brymer \& Mackenzie, 2017; Brymer \& Oades, 2009; Brymer \& Schweitzer, 2013a,b; 2017a,b; Holmbom et al., 2017). At the levels described in this contribution, participants must routinely adopt measures to minimise risks of injury, but they are unlikely to die unless they are unlucky as well as unskilled (Buckley, 2012, 2015a, 2016a,b; 2017). The age range covered is from $<10$ years old, to $>60$ years old (Table 1 ).

\section{Autoethnography of Critical Incidents}

It took some time for autoethnographic methodologies to be accepted as part of the panoply of social science techniques (Anderson, 2006; Pace, 2016). Currently, however, they are used widely (Anderson \& Austin, 2012; Buckley, 2012, 2016b; Chang, 2016; Jones, Adams, \& Ellis, 2016; Scheidt, 2016; Stahlke Wall, 2016; Tolich, 2010). In the study of adventurous nature sports, a key component of autoethnographic approaches is the ability to recall fine detail of events and emotions, even if these are difficult to describe (Buckley, 2015b; Brymer \& Schweitzer, 2017b).

This fine recall is possible for two reasons. The first is that human brains can either perceive or remember potentially life-threatening events in enhanced detail and clarity, the subjective impression of "slow time" (Arstila, 2012; Buckley, 2014; Stetson, Fiesta \& Eagleman, 2007; 
1

2

3

4

5

6

7

8

9
306

307

308

309

310

311

312

313

314

315

316

317

318

319

320

321

322

323

324

325

326

327

328

329

330

331

332

333

334

335

336

337

338

339

340

341

342

343

344

345

346

Wittman, 2011). The second is that the human brain can recall memories of such "critical incidents" in much greater detail than memories more generally, even after a considerable interval has elapsed (Flanagan, 1954; Brown \& Kulik, 1977; Buckley, 2016a). Whilst individuals typically express high confidence in these recollections, the recollections may not always prove to be objectively accurate (Bradburn, Rips, \& Shevell, 1987; Loftus, 2017; Talarico \& Ruben, 2003; Winkler, 2017). The level of detail recalled generally does not decline with age, and may increase (Gardner, Mainetti, \& Ascoli, 2015; Huber, Milne, \& Hyde, 2017; Knäuper et al., 2016).

\section{Data, Generalisation, Abstraction}

I adopt a retrospective analytical autoethnographic approach, as a person who has taken part in a range of outdoor adventure activities for over half a century. I aim firstly, to identify the health outcomes from these adventurous nature sports; and secondly, to track how these outcomes have changed with advancing age. There are thus four categories of primary data. The first category consists of recollections of critical incidents from different nature sports activities, which are sufficiently intense and detailed to include psychological components. The second category consists of recollections of confounding factors that may also have affected physical or mental health, such as injuries unrelated to adventurous nature sports.

The third category consists of general long-term autoethnographic observations on changing motivations, capabilities, experiences and consequences associated with outdoor adventure activities. The fourth consists of reflective observations on: current levels of activity in each of the adventurous nature sports concerned; current levels of physical and mental health and capability; and self-perceptions of the links between nature sports and health at my current age. From these sets of data, I generalise across the different adventure activities, whilst recognising that I pursued different activities most intensely at different ages. I then extract a set of second-level abstractions, representing lifetime changes and trends in higher-tier parameters. These include both physical health parameters such as fitness and flexibility, and mental health parameters such as emotional intensity and generalised self-esteem.

\section{Ethics Statement}

Some of the data presented here were obtained during commercial adventure tours. Assistance and sponsorship of tour operators is gratefully acknowledged. All of the research reported here, including that drawn from previous publications by the same author as well as new research conducted specifically for the current analysis, was conducted in strict compliance with the research ethics requirements of the author's university. This includes adherence to the University Research Ethics Manual and the relevant National Statement on Ethical Conduct in Human Research, and approvals by the University Human Research Ethics Committee as required.

\section{Results}

The adventure activities involved, overall age spans over which they were practiced, and current levels of activity or inactivity, are summarised in Table 1. The relative level of intensity for each activity at different age brackets is shown in Table 2. This indicates successive replacement of activities, with some being carried out in parallel, others sequentially. These changes in relative priority of different adventure activities were due 
partly to changing interests, and partly to their different availability and accessibility in different geographic areas.

Table 3 and Table 4 summarise the highest level of skill achieved in each activity, using two different sets of measures. Table 3 lists external recognition, such as competitions or sponsorships. Table 4 is a self-reflective evaluation, identifying specific achievements of which I myself am internally most proud. That is, Table 4 shows the events or incidents that in my own evaluation, required the highest degree of skill or generated the highest levels of fear or thrill. Comparison of Table 3 and 4 shows that there is very little correspondence between the external and internal measures of achievement. Table 4 also shows that the internally assessed achievements are highly idiosyncratic. Even at summary level such as in Table 4, these critical events or incidents can only be described with reference to very specific geographical sites and environmental characteristics, and prevailing conditions such as weather, river flow, or surf size. Theorists are interested in abstractions, but practitioners want to know details [author, in review].

Table 5 provides these abstractions, summarising lifetime trends or trajectories of change, for a series of physical and psychological parameters. It includes four physical parameters: physical capability, including fitness; the effects of injuries from unrelated sources such as car crashes; chronic pain; and level of stamina and reserves of strength in adversity. It includes five psychological parameters: the ability to overcome fear, both prior to a risky activity and during the progress of the activity itself; the ability to assess one's limits accurately, both physical and mental; the experience of positive emotions such as thrill, joy, and awe; the degree of attention paid to the surrounding natural environment, unrelated to its role in performing the adventure activity; and the degree of self-awareness of how manoeuvres are performed and how new skills are gained. Also included in Table 5 are two contextual parameters. The first is the degree of difficulty of challenges faced or attempted. The second is the self-perceived importance of adventure activities, relative to other components of one's life such as work, social relationships, or other forms of leisure.

Comparing the ageing trajectories for the different parameters in Table 5 leads to the highestlevel finding of this analysis. As age increases, one's abilities decrease; one's attention to surroundings and skills increases; and one's enjoyment of adventure activities remains largely unchanged. Euphoria is achievable at any age, as long as one is physically able to take part in at least some type of adventurous outdoor nature sports at some level of capability. Nature sports can thus contribute to mental health at all ages.

For myself specifically, my abilities are now on the decline for every adventure activity, except perhaps kiteboarding. This applies even though my abilities were never more than intermediate, at best, for any of these activities. I have never learned skydiving (except tandem), let alone BASE jumping or proximity flying. I have never surfed the very large, steep, hollow and powerful waves ridden by professional competitive surfers, and I never shall. I should add that I found it hard to type the final four words of the last sentence, to admit to myself "out loud" that I shall never be capable of surfing Teahupo'o or Shipstern or Nazarre or Peahi or Mavericks or many other such famous waves. Analytically, I know perfectly well that my abilities are orders of magnitude too low to attempt even far smaller and easier waves. But I still don't like to let go of the imaginary possibility. Thirty years ago I was a confident Class IV and occasional Class V whitewater kayaker: currently, I am Class III at best. It is easy enough to admit this to others, and indeed, they know it already. It is hard to admit it to oneself. 
1

2

3

4

5

6

7

8
397

398

399

400

401

402

403

404

405

406

407

408

409

410

411

412

413

414

415

416

417

418

419

420

421

422

423

424

425

426

427

428

429

430

431

432

433

434

435

436

437

438

439

440

441

442

443

444

445

446

The increasing attention paid to one's natural surroundings, as age increases and capabilities decrease, is unexpected. It seems to be a form of compensation, recognising that even though one may not be catching as many waves as the youngsters, one can better appreciate the crystal blue ocean, the dolphins surfing nearby, the sea eagles soaring over the headland, the gannets riding the rising airflow in front of each wave. This seems to be distinct from the very detailed high-speed perception of surroundings associated with high danger, described by Buckley (2016b) for hanggliding in dangerous conditions, and by Holmbom et al. (2017) for proximity flying, that is connected with the phenomenon of "slow time" perception (Buckley, 2014).

\section{Discussion}

Previous research in adventurous outdoor nature sports, and extreme sports in particular, has repeatedly revealed that participants value their experiences enormously. There seem to be three principal reasons. The first reason is that these experiences are: only available through these activities; far outside the realm of experience otherwise available; and so powerful as to transform lives. Brymer and Oades (2009) cited autobiographical reports from kayakers, sailboarders and mountaineers, where single events transformed the entire subsequent lives of those concerned.

Climbers interviewed by Willig (2008) reported that their entire attention was focussed on the present instant. A BASE jumper interviewed by Brymer and Oades (2009) described "how frightening, how exciting, how peaceful and beautiful the sensation is." Brymer \& Schweitzer (2017) quoted a BASE jumper: "it's incredibly, incredibly intense... you're at this level of alertness that you're not in a normal life." Another BASE jumper said that: "your awareness of one second expands enormously... it feels like it's in slow motion... you can see the tiny little creases in the rock and different colours in the sky and you're totally aware." This is the slow-time perception examined by Arstila (2012) and Buckley (2014).

The second reason is that these experiences provide existential meaning. They lead participants to recognise and accept their mortality, and to appreciate and value their lives. Brymer and Oades (2009) quoted a BASE jumper, who said that it involves: "accepting that you're mortal ... vulnerable ... like a piece of dust." Holmbom et al. (2017) quoted proximity wingsuit flyers: "We are all gonna die someday.. you admit that reality and choose to enjoy, live and love the rest of the tiny spark that is our short life in the infinite universe". Or as another said: "we are all going to die .. it is how we LIVE that matters." My own autoethnographic experience suggests that this is the philosophy of most participants in adventurous outdoor nature sports, not only those that pose immediate risks of death.

The third reason is that these experiences generate psychological strength, that can then be applied elsewhere (Hickman et al., 2017). Pain \& Pain (2005) argued that: "despite the public's perception, extreme sports demand perpetual care, high degrees of training and preparation, and above all, discipline and control." Brymer and Oades (2009) quoted a BASE jumper: "fear is a constant companion that requires great psychological skill to overcome". They also quoted a big-wave surfer, who said that "nothing can upset you". Similarly, Holmbom et al. (2017) quoted a proximity wingsuit flyer: "no other challenge is too big." Again, my own experience, albeit at far lower intensities, coincides with those findings. 
447 Previous research on the effects of ageing on participants in adventurous outdoor nature 448 sports has revealed two general effects. The first is that older individuals who are able to 449 continue these activities despite their age are proud of doing so (Hickman et al., 2016; 450 Wheaton, 2017). They identify themselves with their preferred activities (Hickman et al., 451 2016, 2017); and remain addicted to them (Wheaton, 2017). The second is that older 452 participants pay more attention to nature and their surroundings, and savour each moment 453 more intensely than their younger counterparts (Hickman et al., 2016). The results reported 454 here are derived from far less extreme levels of skill and risk than those reported by 455 Holmbom et al. (2017), though perhaps similar to those studied by Hickman et al (2016, 456 2017) and Wheaton (2017). They support both these two previous findings.

457

The results reported here also add several new findings. The most important is that despite loss of capability in adventurous outdoor nature sports, older participants are still able to use those activities to experience euphoria. That euphoria allows them to overcome pain, temporarily. It gives them psychological strength to overcome the stresses of major life transitions, and provides them with continuing meaning to life. Those consequences have considerable value, not only for the health and happiness of individuals, but for the economies of wealthy urbanised nations with ageing populations.

\section{Conclusions}

Continuing enjoyment, even at decreased capability, is the single most important finding from a health perspective. It means that even individuals in older age brackets, in the postworking "Third Age" as defined by Laslett (1991), can maintain their mental health through the intermittent euphoric events associated with adventurous outdoor nature sports. From an economic perspective, it is these older individuals who currently pose the greatest new economic cost on the economies of wealthy urbanised nations (Buckley \& Brough 2017a,b).

Poor mental health of working-age individuals imposes costs on workplace productivity (Powell, 2017); and poor mental health of children and young adults imposes costs through healthcare and antisocial behaviours that may persist throughout their lives (Lee, Adam et al., 2017). These can be counteracted through outdoor nature and adventure therapies, and in many cases they already are (Mojtabai, Olfson, \& Han, 2016). It is the older age brackets, however, where the therapeutic effect of adventurous outdoor nature sports has the greatest social and economic significance. People in wealthy urbanised nations are now living longer than in the past, but they are spending their extra years in an unhealthy state, imposing large social and economic costs through the need for physical and mental health care, aged care, paid or unpaid carers, and assisted living.

Larger proportions of these ageing individuals are now recognising for themselves, however, that they need not relapse into inactivity. They may not be as capable as once they were, but they can still get outdoors, take part in nature sports and adventure activities, and experience occasional euphoria in consequence. The euphoric experiences achieved during those activities provide older individuals, myself included, with a continuing and convincing demonstration that life is still very well worth living, despite injuries, illnesses, chronic pain and stress, and advancing decrepitude. Adventure provides euphoria as well as physical health; euphoria provides positive mental health; and maintaining the mental health of older individuals has high economic value for modern economies. 
497

498

499

500

501

502

503

504

505

506

507

508

509

510

511

512

513

514

515

516

517

518

519

520

521

522

523

524

525

526

527

528

529

530

531

532

533

534

535

536

537

538

539

540

541

542

543

544

545

546

\section{References}

Anderson, L. (2006). Analytic autoethnography. Journal of Contemporary Ethnography, 35, 373-395.

Anderson, L., \& Austin, M. (2012). Auto-ethnography in leisure studies. Leisure Studies, 31, 131-146.

Arijs, C., Stiliani, C., Brymer, G. E., \& Carless, D. (2017). Leave your ego at the door: A narrative investigation into effective wingsuit flying. Frontiers in Psychology (in press).

Arstila, V. (2012). Time slows down during accidents. Frontiers in Psychology, 3, 196.

[author]. (2018). Ageing adventure athletes assess achievements and alter aspirations to maintain self-esteem. Frontiers in Psychology (in review).

Baretta, D., Greco, A., \& Steca, P. (2017). Understanding performance in risky sport: The role of self-efficacy beliefs and sensation seeking in competitive freediving. Personality and Individual Differences, 117, 161-165.

Berman, D., \& Davis-Berman, J. (2013). The role of therapeutic adventure in meeting the mental health needs of children and adolescents: finding a niche in the health care systems of the United States and the United Kingdom. Journal of Experiential Education, 36, 51-64.

Biedenweg, K., Scott, R. P., \& Scott, T. A. (2017). How does engaging with nature relate to life satisfaction? Demonstrating the link between environment-specific social experiences and life satisfaction. Journal of Environmental Psychology, 50, 112-124.

Blaschke, S., O'Callaghan, C. C., Schofield, P., \& Salander, P. (2017). Cancer patients' experiences with nature: Normalizing dichotomous realities. Social Science \& Medicine, 172, 107-114.

Bowen, D. J., Neill, J. T., \& Crisp, S. J. (2016). Wilderness adventure therapy effects on the mental health of youth participants. Evaluation and Program Planning, 58, 49-59

Boyes, M. (2013). Outdoor adventure and successful ageing. Ageing \& Society, 33, 644-665.

Bradburn, N. M., Rips, L. J., \& Shevell, S. K. (1987). Answering autobiographical questions: The impact of memory and inference on surveys. Science, 236, 157-161.

Brannigan, A., \& McDougall, A.A. (1983). Peril and pleasure in the maintenance of a high risk sport: a study of hang-gliding. Journal of Sport Behaviour, 6, 37-51.

Brough, P., Johnson, G., Drummond, S., Pennisi, S., \& Timms, C. (2011). Comparisons of cognitive ability and job attitudes of older and younger workers. Equality, Diversity and Inclusion: An International Journal, 30, 105-126.

Brown, R. \& Kulik, J. (1977). Flashbulb memories. Cognition, 5, 73-99. 
547 Brymer, E. (2013). Risk and extreme sports: a phenomenological perspective. Annals of Leisure 548 Research, 13, 218-39.

549

550

551

552

553

554

555

556

557

558

559

560

561

562

563

564

565

566

567

568

569

570

571

572

573

574

575

576

577

578

579

580

581

582

583

584

585

586

587

588

589

590

591

592

593

594

595

596
Brymer, E., \& Mackenzie, S. H. (2017). Psychology and the extreme sport experience. In F. Felletti (ed.), Extreme Sports Medicine, pp. 3-13. Springer, Switzerland.

Brymer, E., \& Oades, L. (2009). Extreme sports: A positive transformation in courage and humility. Journal of Humanistic Psychology, 49, 114-126.

Brymer, E., \& Schweitzer, R. (2013a). Extreme sports are good for your health: A phenomenological understanding of fear and anxiety in extreme sport. Journal of Health Psychology, 18, 477-487.

Brymer, E., \& Schweitzer, R. (2013b). The search for freedom in extreme sports: a phenomenological exploration. Psychology of Sport and Exercise, 14, 865-873.

Brymer, E., \& Schweitzer, R. (2017a). Phenomenology and the Extreme Sport Experience. Taylor \& Francis.

Brymer, E., \& Schweitzer, R. D. (2017b). Evoking the ineffable: The phenomenology of extreme sports. Psychology of Consciousness: Theory, Research, and Practice, 4, 63-74.

Buckley, R.C. (2012). Rush as a key motivation in skilled adventure tourism: Resolving the risk recreation paradox. Tourism Management, 33, 961-970.

Buckley, R.C. (2014). Slow time perception can be learned. Frontiers in Psychology, 5, 209.

Buckley, R. C. (2015a). Adventure thrills are addictive. Frontiers in Psychology, 6, 1915.

Buckley, R.C. (2015b). Autoethnography helps analyse emotions. Frontiers in Psychology, 6, 209.

Buckley, R.C. (2016a). Qualitative analysis of emotions: fear and thrill. Frontiers in Psychology, 7, 1187.

Buckley, R.C. (2016b). Nature fix: addiction to outdoor activities. Journal of Behavioural Addiction, 5, 557-558.

Buckley, R.C. (2017). Analysing adventure: a leisure lifepsychle? Annals of Leisure

Research, doi: 10.1080/11745398.2017.1361333

Buckley, R.C. \& Brough, P. (2017a). Nature, eco and adventure therapies for mental health and chronic disease. Frontiers in Public Health, 5, 220.

Buckley, R.C. \& Brough, P. (2017b). Economic value of parks via human mental health.

Frontiers in Ecology and Evolution, 5, 16.

Buckley, R.C., Brough, P. \& Westaway, D. (in review). Matching outdoor therapies to patient mental health. Frontiers in Public Health, 
597 Buckley, R., Gretzel, U., Scott, D., Weaver, D., \& Becken, S. (2015). Tourism megatrends.

598 Tourism Recreation Research, 40, 59-70.

599

600

601

602

603

604

605

606

607

608

609

610

611

612

613

614

615

616

617

618

619

620

621

622

623

624

625

626

627

628

629

630

631

632

633

634

635

636

637

638

639

640

641

642

643

644

645

Buckley, R.C., Westaway, D. and Brough, P. (2016). Social mechanisms to get people outdoors. Frontiers in Public Health, 4, 257.

Chang, H. (2016). Autoethnography as Method. Routledge, London.

Clough, P., Mackenzie, S. H., Mallabon, L., \& Brymer, E. (2016). Adventurous physical activity environments: A mainstream intervention for mental health. Sports Medicine, 46, 963-968.

Coon, J. T., Boddy, K., Stein, K., Whear, R., Barton, J., \& Depledge, M. H. (2011). Does participating in physical activity in outdoor natural environments have a greater effect on physical and mental well-being than physical activity indoors? A systematic review.

Environmental Science and Technology, 45, 1761-1772.

DiPietro, L., Jin, Y., Talegawkar, S., \& Matthews, C. E. (2017). The joint associations of sedentary time and physical activity with mobility disability in older people: NIH-AARP Diet and Health Study. Journals of Gerontology Series A, glx122.

Earl, B. (2014). The biological function of consciousness. Frontiers in Psychology, 5, 697.

Elmes, M., \& Barry, D. (1999). Deliverance, denial, and the Death Zone: a study of narcissism and regression in the May 1996 Everest climbing disaster. Journal of Applied Behavioural Science, 35, 163-187.

Epstein, I. (2004). Adventure therapy: a mental health promotion strategy in pediatric oncology. Journal of Pediatric Oncology and Nursing, 21, 103-110.

Erickson, K. I., Leckie, R. L., \& Weinstein, A. M. (2014). Physical activity, fitness, and gray matter volume. Neurobiology of Aging, 35, S20-S28.

Ewert, A, \& Yoshino, A. (2011). The influence of short-term adventure based experiences on levels of resilience. Journal of Adventure Education and Outdoor Learning, 11, 35-50.

Flanagan, J. C. (1954) The critical incident technique. Psychological Bulletin, 51, 327-358.

Frühauf, A., Niedermeier, M., Elliott, L. R., Ledochowski, L., Marksteiner, J., \& Kopp, M. (2016). Acute effects of outdoor physical activity on affect and psychological well-being in depressed patients-A preliminary study. Mental Health and Physical Activity, 10, 4-9.

Frumkin, H., Bratman, G. N., Breslow, S. J., Cochran, B., Kahn Jr, P. H., Lawler, J. J., ... \& Wood, S. A. (2017). Nature contact and human health: A research agenda. Environmental Health Perspectives, 125, 075001-1.

Gardner, R.S., Mainetti, M., \& Ascoli, G.A. (2015). Older adults report moderately more detailed autobiographical memories. Frontiers in Psychology, 6, 631. 
646 Gass, M. A., Gillis, H. L., \& Russell, K. C. (2012). Adventure Therapy: Theory, Research, and 647 Practice. New York: Routledge.

648

649

650

651

652

653

654

655

656

657

658

659

660

661

662

663

664

665

666

667

668

669

670

671

672

673

674

675

676

677

678

679

680

681

682

683

684

685

686

687

688

689

690

691

692

693

694

695
Gomez-Pinilla, F., \& Hillman, C. (2013). The influence of exercise on cognitive abilities.

Comprehensive Physiology, 3, 403-428.

Grubb, M. A., Tymula, A., Gilaie-Dotan, S., Glimcher, P. W., \& Levy, I. (2016). Neuroanatomy accounts for age-related changes in risk preferences. Nature Communications, 7, 13822.

Harvey, S. B., Øverland, S., Hatch, S. L., Wessely, S., Mykletun, A., \& Hotopf, M. (2017). Exercise and the prevention of depression: results of the HUNT Cohort Study. American Journal of Psychiatry, doi: 10.1176/appi.ajp.2017.16111223.

Hattie, J., Marsh, H.W., Neill, J.T., \& Richards, G. E. (1997). Adventure education and outward bound: out-of-class experiences that make a lasting difference. Review of Educational Research, $67,43-87$.

Hendriks, I. H., van Vliet, D., Gerritsen, D. L., \& Dröes, R. M. (2016). Nature and dementia: development of a person-centered approach. International Psychogeriatrics, 28, 1455-1470.

Hickman, M., Stokes, P., Beard, C., \& Inkster, A. (2017). Doing the plastic fantastic: 'artificial' adventure and older adult climbers. Journal of Adventure Education and Outdoor Learning, doi: 10.1080/14729679.2017.1308874

Hickman, M., Stokes, P., Gammon, S., Beard, C., \& Inkster, A. (2016). Moments like diamonds in space: savoring the ageing process through positive engagement with adventure sports. Annals of Leisure Research, doi: 10.1080/11745398.2016.1241151

Holm, M. R., Lugosi, P., Croes, R. R., \& Torres, E. N. (2017). Risk-tourism, risk-taking and subjective well-being: A review and synthesis. Tourism Management, 63, 115-122.

Holmbom, M., Brymer, E., \& Schweitzer, R. D. (2017). Transformations through proximity flying: A phenomenological investigation. Frontiers in Psychology, 8, 1831.

Huber, D., Milne, S., \& Hyde, K. F. (2017). Biographical research methods and their use in the study of senior tourism. International Journal of Tourism Research, 19, 27-37.

Immonen, T., Brymer, E., Orth, D., Davids, K., Feletti, F., Liukkonen, J., \& Jaakkola, T. (2017). Understanding action and adventure sports participation: an ecological dynamics perspective. Sports Medicine - Open, 3, 18.

Jepson, P., Caldecott, B., Schmitt, S. F., de Carvalho, S. H. C., Correia, R. A., Malhado, A. C. M., ... \& Ladle, R. J. (2017). Protected area asset stewardship. Biological Conservation, 212, 183-190.

Jones, S.H., Adams, T.E., \& Ellis, C. (Eds.). (2016). Handbook of Autoethnography. Routledge, London.

Knäuper, B., Carriere, K., Chamandy, M., Xu, Z., Schwarz, N., \& Rosen, N. O. (2016). How

aging affects self-reports. European Journal of Ageing, 13, 185-193. 
696 Laslett, P. (1991). A Fresh Map of Life: The Emergence of the Third Age (2 ${ }^{\text {nd }}$ edn) Harvard

697 University Press, Cambridge MA.

698

699

700

701

702

703

704

705

706

707

708

709

710

711

712

713

714

715

716

717

718

719

720

721

722

723

724

725

726

727

728

729

730

731

732

733

734

735

736

737

738

739

740

741

742

743
Leckie, R. L., Weinstein, A. M., Hodzic, J. C., \& Erickson, K. I. (2012). Potential moderators of physical activity on brain health. Journal of Aging Research, 2012, 948981.

Lee, D. C., Brellenthin, A. G., Thompson, P. D., Sui, X., Lee, I. M., \& Lavie, C. J. (2017).

Running as a key lifestyle medicine for longevity. Progress in Cardiovascular Diseases, 60, 45-55.

Lee, B. Y., Adam, A., Zenkov, E., Hertenstein, D., Ferguson, M. C., Wang, P. I., ... \& FalahFini, S. (2017). Modeling the economic and health impact of increasing children's physical activity in the United States. Health Affairs, 36, 902-908.

Loftus, E.F. (2017). Eavesdropping on memory. Annual Review of Psychology, 68, 1-18.

Luttenberger, K., Stelzer, E. M., Först, S., Schopper, M., Kornhuber, J., \& Book, S. (2015). Indoor rock climbing (bouldering) as a new treatment for depression: study design of a waitlist-controlled randomized group pilot study and the first results. BMC Psychiatry, 15, 201.

Mantler, A., \& Logan, A. C. (2015). Natural environments and mental health. Advances in Integrative Medicine, 2, 5-12.

Melo, R., \& Gomes, R. (2017). Nature sports participation: Understanding demand, practice profile, motivations and constraints. European Journal of Tourism Research, 16, 108-135.

Miesel, M.E., \& Potgieter, J.R. (2003). The experience of fear in high-risk sport. South African Journal of Research in Sport, Physical Education and Recreation, 25, 49-56.

Mojtabai, R., Olfson, M., \& Han, B. (2016). National trends in the prevalence and treatment of depression in adolescents and young adults. Pediatrics, 138, e20161878.

Monasterio, E., Mei-Dan, O., Hackney, A. C., Lane, A. R., Zwir, I., Rozsa, S., \& Cloninger, C. R. (2016). Stress reactivity and personality in extreme sport athletes: The psychobiology of BASE jumpers. Physiology \& Behavior, 167, 289-297.

Moore, L. E., \& Greyson, B. (2017). Characteristics of memories for near-death experiences. Consciousness and Cognition, 51, 116-124.

Niedermeier, M., Einwanger, J., Hartl, A., \& Kopp, M. (2017). Affective responses in mountain hiking: a randomized crossover trial focusing on differences between indoor and outdoor activity. PloS ONE, 12, e0177719.

Niedermeier, M., Hartl, A., \& Kopp, M. (2017). Prevalence of mental health problems and factors associated with psychological distress in mountain exercisers: a cross-sectional study in Austria. Frontiers in Psychology, 8, 1237. 
744 O’Donovan, G., Lee, I. M., Hamer, M., \& Stamatakis, E. (2017). Association of "weekend 745 warrior" and other leisure time physical activity patterns with risks for all-cause,

746 cardiovascular disease, and cancer mortality. JAMA Internal Medicine, 177, 335-342.

747

748

749

750

751

752

753

754

755

756

757

758

759

760

761

762

763

764

765

766

767

768

769

770

771

772

773

774

775

776

777

778

779

780

781

782

783

784

785

786

787

788

789

790

791
Oh, B., Lee, K. J., Zaslawski, C., Yeung, A., Rosenthal, D., Larkey, L., \& Back, M. (2017). Health and well-being benefits of spending time in forests: systematic review. Environmental Health and Preventive Medicine, 22, 71.

Orth, U., Maes, J., \& Schmitt, M. (2015). Self-esteem development across the life span: A longitudinal study with a large sample from Germany. Developmental Psychology, 51, 248259.

Pace, S. (2016). Contested concepts: negotiating debates about qualitative research methods such as grounded theory and autoethnography. In Constructing Methodology for Qualitative Research (pp. 187-200). Palgrave Macmillan, UK.

Pain, M.T., \& Pain, M.A. (2005). Essay: risk taking in sport. The Lancet, 366, 33-34.

Pasanen, T. P., Tyrväinen, L., \& Korpela, K. M. (2014). The relationship between perceived health and physical activity indoors, outdoors in built environments, and outdoors in nature. Applied Psychology: Health and Well $\square$ Being, 6, 324-346.

Pedersen, B. K., \& Saltin, B. (2015). Exercise as medicine-evidence for prescribing exercise as therapy in 26 different chronic diseases. Scandinavian Journal of Medicine \& Science in Sports, 25(S3), 1-72.

Pomfret, G., \& Bramwell, B. (2016). The characteristics and motivational decisions of outdoor adventure tourists: a review and analysis. Current Issues in Tourism, 19(, 1447-1478.

Portugal, A.C., Campos, F., Martins, F., \& Melo, R. (2017). Understanding the relation between serious surfing, surfing profile, surf travel behaviour and destination attributes preferences.

European Journal of Tourism Research, 16, 57-73.

Powell, K. (2017). Work-life balance: Break or burn out. Nature, 545, 375-377.

Pryor, A., Carpenter, C., \& Townsend, M. (2012). Outdoor education and bush adventure therapy: A social-ecological approach to health and wellbeing. Australian Journal of Outdoor Education, 9, 3-13.

Puchan, H. (2004). Living 'extreme': adventure sports, media and commercialisation. Journal of Communication Management, 9, 171-178.

Rabarison, K. M., Bish, C. L., Massoudi, M. S., \& Giles, W. H. (2015). Economic evaluation enhances public health decision making. Frontiers in Public Health, 3, 164.

Russell, K.C. (2003). An assessment of outcomes in outdoor behavioural healthcare treatment. Child Youth Care Forum, 32, 355-381. 
792

793

794

795

796

797

798

799

800

801

802

803

804

805

806

807

808

809

810

811

812

813

814

815

816

817

818

819

820

821

822

823

824

825

826

827

828

829

830

831

832

833

834

835

836

837

838

839

840
Sah, N., Peterson, B. D., Lubejko, S. T., Vivar, C., \& van Praag, H. (2017). Running reorganizes the circuitry of one-week-old adult-born hippocampal neurons. Scientific Reports, 7, 10903.

Sandseter, E. B. H., \& Kennair, L. E. O. (2011). Children's risky play from an evolutionary perspective: The anti-phobic effects of thrilling experiences. Evolutionary Psychology, 9, 257-284.

Scheidt, R. J. (2016). The defense of my aging self: a report from the field. The

Gerontologist, 57, 110-115.

Scrutton, R., \& Beames, S. (2015). Measuring the unmeasurable: Upholding rigor in quantitative studies of personal and social development in outdoor adventure education. Journal of Experiential Education, 38, 8-25.

Seifert, L., Orth, D., Button, C., Brymer, E., \& Davids, K. (2017). An ecological dynamics framework for the acquisition of perceptual-motor skills in climbing. In Extreme Sports Medicine (pp. 365-382). Springer International Publishing.

Seymour, V. (2016). The human-nature relationship and its impact on health: a critical review. Frontiers in Public Health, 4, 260.

Sibthorp, J., \& Arthur-Banning, S. (2004). Developing life effectiveness through adventure education: The roles of participant expectations, perceptions of empowerment, and learning relevance. Journal of Experiential Education, 27, 32-50.

Sibthorp, J., Paisley, K., Gookin, J., \& Furman, N. (2008). The pedagogic value of student autonomy in adventure education. Journal of Experiential Education, 31, 136-151.

Stahlke Wall, S. (2016). Toward a moderate autoethnography. International Journal of Qualitative Methods, 15, doi: 10.1177/1609406916674966.

Steptoe, A., Deaton, A., \& Stone, A. A. (2015). Subjective wellbeing, health, and ageing. The Lancet, 385, 640-648.

Stetson, C., Fiesta, M. P., \& Eagleman, D. M. (2007). Does time really slow down during a frightening event? PloS ONE, 2, e1295.

Sun, F. W., Stepanovic, M. R., Andreano, J., Barrett, L. F., Touroutoglou, A., \& Dickerson, B. C. (2016). Youthful brains in older adults: Preserved neuroanatomy in the default mode and salience networks contributes to youthful memory in superaging. Journal of Neuroscience, 36, 9659-9668.

Talarico, J.M. \& Rubin, D.C. (2003). Confidence, not consistency, characterizes flashbulb memories. Psychological Science, 14, 455-461.

Thonnard, M., Charland-Verville, V., Brédart, S., Dehon, H., Ledoux, D., Laureys, S., \& Vanhaudenhuyse, A. (2013). Characteristics of near-death experiences memories as compared to real and imagined events memories. PLoS ONE, 8, e57620. 
841

842

843

844

845

846

847

848

849

850

851

852

853

854

855

856

857

858

859

860

861

862

863

864

865

866

867

868

869

870

871

872

873

874

875

876

877

878

879

880

881

882

883

884

885

886

887

888

889
Tolich, M. (2010). A critique of current practice: Ten foundational guidelines for autoethnographers. Qualitative Health Research, 20, 1599-1610.

Triguero-Mas, M., Donaire-Gonzalez, D., Seto, E., Valentín, A., Smith, G., Martínez, D., ... \& Martínez-Íñiguez, T. (2017). Living close to natural outdoor environments in four European cities: adults' contact with the environments and physical activity. International Journal of Environmental Research and Public Health, 14, 1162.

Van Beek, S. (1998). The power of one. Explorer's Journal, 1998, 22-29.

Vivar, C., \& van Praag, H. (2017). Running changes the brain: the long and the short of it. Physiology, 32, 410-424.

Wang, R. A. H., Nelson-Coffey, S. K., Layous, K., Bao, K. J., Davis, O. S., \& Haworth, C. M. (2017). Moderators of wellbeing interventions: Why do some people respond more positively than others? PloS ONE, 12, e0187601.

Wheaton, B. (2017). Surfing through the life-course: silver surfers' negotiation of ageing. Annals of Leisure Research, 20, 96-116.

Willig, C. (2008). A phenomenological investigation of the experience of taking part in 'extreme sports'. Journal of Health Psychology, 13, 690-702.

Winkler, I. (2017). Doing autoethnography: facing challenges, taking choices, accepting responsibilities. Qualitative Inquiry, doi: 10.1177/1077800417728956.

Wittmann, M. (2011). Moments in time. Frontiers in Integrative Neuroscience, 5, 66.

Wooden, M., \& Li, N. (2016). Ageing, death and life satisfaction: evidence from the Household, Income and Labour Dynamics in Australia survey. Australian Economic Review, 49, 474-482.

Woodman, T., Hardy, L., Barlow, M., \& Le Scanff, C. (2010). Motives for prolonged engagement high-risk sports: an agentic emotion regulation perspective. Psychology of Sport and Exercise, 11, $345-352$.

Wyles, K. J., White, M. P., Hattam, C., Pahl, S., King, H., \& Austen, M. (2017). Are some natural environments more psychologically beneficial than others? The importance of type and quality on connectedness to nature and psychological restoration. Environment and Behavior, doi: $10.1177 / 0013916517738312$.

Young, K. C., Machell, K. A., Kashdan, T. B., \& Westwater, M. L. (2017). The cascade of positive events: Does exercise on a given day increase the frequency of additional positive events? Personality and Individual Differences, doi: 10.1016/j.paid.2017.03.032

Zeisel, J., Reisberg, B., Whitehouse, P., Woods, R., \& Verheul, A. (2016). Ecopsychosocial interventions in cognitive decline and dementia: A new terminology and a new paradigm.

American Journal of Alzheimer's Disease \& Other Dementias, 31, 502-507. 
890

891

892

\begin{tabular}{|l|c|c|c|l|}
\hline Activity & $\begin{array}{c}\text { Start } \\
\text { age }\end{array}$ & $\begin{array}{c}\text { Age of } \\
\text { peak skill }\end{array}$ & $\begin{array}{c}\text { End } \\
\text { age }\end{array}$ & Current level of activity \\
\hline & & & & \\
\hline Ski, telemark & 5 & 40 & 45 & inactive, still have gear \\
\hline Snowboard & 45 & 50 & 55 & inactive, still have gear \\
\hline Hangglide & 20 & 25 & 25 & inactive, still have gear \\
\hline Kayak, flatwater & 10 & 18 & n/a & active, low key, local \\
\hline Kayak, whitewater & 35 & 45 & n/a & active, low skill, global \\
\hline Seakayak \& surfski & 40 & 50 & n/a & active, mod skill, local \\
\hline Sailboard, flatwater & 20 & 25 & 25 & inactive, still have gear \\
\hline Sailboard, waves & 35 & 45 & n/a & very occasional, local \\
\hline Surf & 45 & 60 & n/a & frequent, skill declining \\
\hline Kiteboard & 58 & 63 & n/a & frequent, mod skill, local \\
\hline
\end{tabular}

893

894

895

896

897

898

899

900

901

902

Table 1. Autoethnographic history of nature-based adventure activities

Table 2. Successive replacement of self-perceived priority adventure activities

\begin{tabular}{|l|c|c|c|c|c|c|}
\hline Activity & \multicolumn{6}{|c|}{ Age ranges and intensity of activity } \\
\hline & $<\mathbf{2 0}$ & $\mathbf{2 0 - 3 0}$ & $\mathbf{3 0 - 4 0}$ & $\mathbf{4 0 - 5 0}$ & $\mathbf{5 0 - 6 0}$ & $>\mathbf{6 0}$ \\
\hline & & & & & & \\
\hline Ski, telemark & $*$ & $* * *$ & $*$ & & & \\
\hline Snowboard & & & & $* * *$ & $* * *$ & \\
\hline Hangglide & $* * * *$ & $*$ & $*$ & $*$ & $*$ & $*$ \\
\hline Kayak, flatwater & & & $* *$ & $* * * *$ & $* * *$ & $*$ \\
\hline Kayak, whitewater & & & & $* *$ & $* *$ & $* *$ \\
\hline Seakayak \& surfski & & $* *$ & & & & \\
\hline Sailboard, flatwater & & $*$ & $* * * *$ & $* * * *$ & $* *$ & $*$ \\
\hline Sailboard, waves & & & & $* *$ & $* * * *$ & $* * * *$ \\
\hline Surf & & & & & & $* * * *$ \\
\hline Kiteboard & & & & & & \\
\hline
\end{tabular}

${ }^{+}$Stars indicate relative intensity of activity cf. other age brackets within same activity. 
Table 3. Intensity, skill levels, and measures of attainment in adventure activities

\begin{tabular}{|l|l|l|l|}
\hline Activity & Intensity & Skill & Achievement, external recognition \\
\hline $\begin{array}{l}\text { Ski, downhill } \\
\text { \& telemark }\end{array}$ & intermittent & low & nil \\
\hline Snowboard & moderate & moderate & $\begin{array}{l}\text { Sponsored by manufacturer (Burton®) } \\
\text { and heli companies (CMH, MWHS, etc) }\end{array}$ \\
\hline Hangglide & addicted & moderate & $\begin{array}{l}\text { 1 Australian, 1 international } \\
\text { competition, 1 brief) record, circa } 1978\end{array}$ \\
\hline $\begin{array}{l}\text { Kayak, } \\
\text { flatwater }\end{array}$ & moderate & moderate & $\begin{array}{l}\text { Cambridge University half-blue, for race } \\
\text { against Oxford, circa 1973 }\end{array}$ \\
\hline $\begin{array}{l}\text { Kayak } \\
\text { whitewater }\end{array}$ & moderate & moderate & $\begin{array}{l}\text { International travel, lead kayaker in first } \\
\text { descents, sponsored by manufacturer }\end{array}$ \\
\hline $\begin{array}{l}\text { Seakayak, } \\
\text { surfski }\end{array}$ & moderate & moderate & $\begin{array}{l}\text { International travel to seakayak, eg } \\
\text { Arctic x 2, supported \& unsupported }\end{array}$ \\
\hline $\begin{array}{l}\text { Sailboard, } \\
\text { flatwater }\end{array}$ & moderate & moderate & $\begin{array}{l}\text { Invited to make a commercial for a } \\
\text { major tobacco company (!), circa } 1980\end{array}$ \\
\hline $\begin{array}{l}\text { Sailboard, } \\
\text { wavesailing }\end{array}$ & addicted & moderate & $\begin{array}{l}\text { Took part in world first international } \\
\text { wave-sailing competition, circa } 1980\end{array}$ \\
\hline Surf & addicted & moderate & $\begin{array}{l}\text { International travel, sponsored by surf } \\
\text { tour companies, shaper (Byrning Spears) }\end{array}$ \\
\hline Kiteboard & addicted & moderate & nil \\
\hline
\end{tabular}

Table 4. Highest self-perceived achievement in each adventure activity

\begin{tabular}{|l|l|}
\hline Activity & Highest self-perceived achievements, defined by personal pride \\
\hline $\begin{array}{l}\text { Ski, downhill } \\
\text { \& telemark }\end{array}$ & $\begin{array}{l}\text { XC-ski snow camping, Yellowstone NP, -40 C C; skied "the Funnel", } \\
\text { back side of Mt Carruthers, Kosciuszko NP, in lightweight tele gear. }\end{array}$ \\
\hline $\begin{array}{l}\text { Snowboard, } \\
\text { freeride }\end{array}$ & $\begin{array}{l}\text { High-speed tree runs as (rotating) lead of heliski groups, Canada; } \\
\text { successful (small) jumps from cornices, outcrops, tree pillows, etc. }\end{array}$ \\
\hline Hangglide & $\begin{array}{l}\text { Cross-country thermal flights, cliff take-offs, wingovers (aerobatic } \\
\text { manoeuvre), landing in strong wind with passenger riding on back. }\end{array}$ \\
\hline $\begin{array}{l}\text { Kayak, } \\
\text { flatwater }\end{array}$ & $\begin{array}{l}\text { Paddled racing ski on flatwater river in Anaconda multisport team } \\
\text { event, passed >50\% of competitors (but the slowest 50\%). }\end{array}$ \\
\hline $\begin{array}{l}\text { Kayak } \\
\text { whitewater }\end{array}$ & $\begin{array}{l}\text { Infierno Canyon \& Terminator, Futaleufu (guided); No Exit, Mekong } \\
\text { (only kayak run); Maruia Falls, New Zealand; Las Leones, Chile. }\end{array}$ \\
\hline $\begin{array}{l}\text { Seakayak, } \\
\text { surfski }\end{array}$ & $\begin{array}{l}\text { 10 days, Baffin Island, Arctic (commercial trip, but unsupported); } \\
\text { surfing (small) ocean surf on racing surfski, Gold Coast, Australia. }\end{array}$ \\
\hline $\begin{array}{l}\text { Sailboard, } \\
\text { flatwater }\end{array}$ & $\begin{array}{l}\text { High-speed run (short, before crash) in 60 knot wind on Cobra carbon } \\
\text { speedboard, Adelaide; overtaking jetski on same board, Gold Coast. }\end{array}$ \\
\hline $\begin{array}{l}\text { Sailboard, } \\
\text { wavesailing }\end{array}$ & $\begin{array}{l}\text { (Maybe 3-4 times in 25 years) rode ocean swells to twice mast height } \\
\text { (8-10m vertical face) during storms and cyclones on Gold Coast. }\end{array}$ \\
\hline $\begin{array}{l}\text { Surf, } \\
\text { shortboard }\end{array}$ & $\begin{array}{l}\text { Cyclone swells, Kirra, Snapper, Burleigh, Australia; surfed HT's, } \\
\text { Icelands, Lighthouses etc, Mentawais, Indonesia (very cautiously!). }\end{array}$ \\
\hline $\begin{array}{l}\text { Kiteboard, } \\
\text { twin-tip }\end{array}$ & $\begin{array}{l}\text { (occasional and unexpected) jumps to >10m vertical altitude, with } \\
\text { 12m kite in 25-30 knot winds, Gold Coast; riding cyclone swells. }\end{array}$ \\
\hline
\end{tabular}


909

910

911

\begin{tabular}{|l|l|}
\hline Parameter & Trajectory over time, as perceived autoethnographically \\
\hline $\begin{array}{l}\text { Physical capability } \\
\text { including fitness }\end{array}$ & $\begin{array}{l}\text { Peaked around age 20, declining ever since, currently (age 63) } \\
\text { a very severe limitation, including cardiovascular, flexibility. }\end{array}$ \\
\hline $\begin{array}{l}\text { Effect of injuries } \\
\text { (not from adventure) }\end{array}$ & $\begin{array}{l}\text { Spinal injuries greatly restrict ability to travel to sites, and } \\
\text { activities themselves; restrictions worsen greatly with age. }\end{array}$ \\
\hline $\begin{array}{l}\text { Stamina, reserves of } \\
\text { strength in adversity }\end{array}$ & $\begin{array}{l}\text { Persisted reasonably well until aged in forties, declined } \\
\text { greatly in fifties, and now in sixties, shadow of former self. }\end{array}$ \\
\hline $\begin{array}{l}\text { Chronic pain } \\
\text { (all sources) }\end{array}$ & $\begin{array}{l}\text { Continuing expansion in intensity, extent, and debilitating } \\
\text { effect, currently a significant restriction on all activities. }\end{array}$ \\
\hline $\begin{array}{l}\text { Overcoming fear } \\
\text { (pre and in event) }\end{array}$ & $\begin{array}{l}\text { Difficult to recall, except for the most severe moments of fear. } \\
\text { Now, when avoiding challenges, is it realism or cowardice? }\end{array}$ \\
\hline $\begin{array}{l}\text { Recognising limits } \\
\text { (physical, mental) }\end{array}$ & $\begin{array}{l}\text { Two key thresholds: (a) no longer a leader; and (b) becoming } \\
\text { a burden on others. Major adjustments to self-esteem needed. }\end{array}$ \\
\hline $\begin{array}{l}\text { Positive emotions } \\
\text { (thrill, joy, awe) }\end{array}$ & $\begin{array}{l}\text { Can recall instances of thrill and joy dating back to age in } \\
\text { twenties, and still continue currently, so not sure of any trend. }\end{array}$ \\
\hline $\begin{array}{l}\text { Attention to nature, } \\
\text { detail of setting }\end{array}$ & $\begin{array}{l}\text { Detailed observation and attention to nature since early age, } \\
\text { still continues currently, can't detect any trend. }\end{array}$ \\
\hline $\begin{array}{l}\text { Awareness of skill } \\
\text { (how it is gained) }\end{array}$ & $\begin{array}{l}\text { Increases with age. At younger age, easier to gain new skills, } \\
\text { but don't know how. When older, difficult, observe carefully. }\end{array}$ \\
\hline $\begin{array}{l}\text { Challenges faced } \\
\text { (degree of difficulty) }\end{array}$ & $\begin{array}{l}\text { Challenges faced at different ages for different activities (see } \\
\text { Tables 1,2). For most, declined since age forties or fifties. }\end{array}$ \\
\hline $\begin{array}{l}\text { Importance in life } \\
\text { (eg cf. work, other) }\end{array}$ & $\begin{array}{l}\text { Always important implicitly, but with greater age and more } \\
\text { restricted ability, importance recognised clearly \& explicitly. }\end{array}$ \\
\hline
\end{tabular}

Table 5. Autoethnographic trajectory of physical and psychological parameters
912

913

914

915 